\title{
Enhanced thrombolytic efficacy and reduction of infarct size by simultaneous infusion of streptokinase and heparin
}

Giovanni Melandri, Angelo Branzi, Franco Semprini, Vittorio Cervi, Nazzareno Galiè, Bruno Magnani

\begin{abstract}
Because paradoxical increase in thrombin activity was reported after the administration of streptokinase in patients with acute myocardial infarction the velocity of reperfusion and degree of myocardial damage were studied when heparin was infused during rather than after streptokinase infusion. Thirty seven consecutive patients with acute myocardial infarction were randomised to receive intravenous heparin during (group 1 , $\mathbf{n}=18$ ) or after (group $2, \mathbf{n}=19$ ) streptokinase (1.5 megaunits over 60 minutes). Markers of reperfusion were monitored every 15 minutes for 3 hours. The serum concentration of creatine kinase was measured every 2 hours. The two groups were similar in terms of age and sex distribution, infarct site, time to treatment, and baseline myocardial ischaemia. Patients in group 1 had a significantly shorter mean (SD) reperfusion time (57 (35) minutes $v 101$ (47)). From 60 to 120 minutes after randomisation there were significant differences in ST segment elevation between the groups. Serum creatine kinase $M B$ peaked earlier (8 (2) hours) in group 1 than in group 2 (10 (4) hours). The peak concentration was significantly lower in group 1 (87 (47) $\mathrm{mU} / \mathrm{ml}$ ) than in group 2 (134 (96) $\mathrm{mU} / \mathrm{ml})$ and infarcts were smaller $(25 \cdot 2(9 \cdot 8)$ gram equivalents $/ \mathrm{m}^{2}$ ) in group 1 than in group 2 $\left(35 \cdot 1(10 \cdot 2)\right.$ gram equivalents $\left./ \mathrm{m}^{2}\right)$.

Simultaneous infusion of heparin and streptokinase speeds up the appearance of signs of reperfusion and reduces infarct size.
\end{abstract}

Institute of
Cardiology,
University of Bologna,
Italy
G Melandri
A Branzi
F Semprini
V Cervi
N Galiè
B Magnani
Correspondence to
Dr Giovanni Melandri,
Istituto di Cardiologia,
Policlinico S Orsola,
Via Massarenti 9,
40138 Bologna, Italy
Accepted for publication
20 November 1989

The role of heparin in the treatment of acute myocardial infarction by thrombolysis is still controversial. Some recommend intravenous heparin from the start of thrombolytic treatment, ${ }^{12}$ and others immediately ${ }^{34}$ or $2-6$ hours $^{56}$ after the infusion of the thrombolytic agent. Recent large clinical trials of thrombolytic treatment in acute myocardial infarction considered heparin as an option. ${ }^{78}$ Thrombin concentration increased in acute myocardial infarction ${ }^{10}$ and again paradoxically after streptokinase or urokinase was given. ${ }^{11}{ }^{12}$

We studied the thrombolytic efficacy of a simultaneous infusion of streptokinase and heparin in patients with acute myocardial infarction.

\section{Patients and methods \\ PATIENTS}

Patients with $\geqslant 30 \mathrm{~min}$ of ischaemic chest pain (unrelieved by sublingual glyceryl trinitrate) and ST segment elevation ( $\geqslant 0.1 \mathrm{mV}$ in two or more standard frontal plane leads or $\geqslant 0.2 \mathrm{mV}$ in two or more precordial leads) were eligible for the study. Patients were not eligible if more than 3 hours had elapsed since the onset of chest pain. Additional exclusion factors were age $>70$ years, uncontrolled hypertension (diastolic pressure $>110 \mathrm{~mm} \mathrm{Hg}$; systolic pressure $>200 \mathrm{~mm} \mathrm{Hg}$ ), a cerebrovascular accident within the past 3 months, known haemorrhagic diathesis or active haemorrhage, an important surgical procedure within the past 2 months, previous coronary artery bypass grafting, prolonged cardiopulmonary resuscitation, oral anticoagulant treatment, childbearing age in women, or serious advanced illness.

\section{TREATMENT PROTOCOL}

All patients received an intravenous infusion of streptokinase ( 1.5 megaunits over $1 \mathrm{~h}$ ). Each patient was randomly assigned to receive either a simultaneous infusion of heparin (aiming at an activated partial thromboplastin time of 2.0 to 2.5 times normal) (group 1) or saline (group 2). At the end of streptokinase infusion group 2 patients were given heparin (according to the same protocol as group 1). Intravenous heparin was continued for 4-5 days provided that there was no serious bleeding. Subsequently patients were placed on an antiplatelet regimen consist- N ing of aspirin (400 $\mathrm{mg}$ per day) and $\underset{\omega}{N}$ dipyridamole (75 $\mathrm{mg}$ three times per day). O During the first $24-48 \mathrm{~h}$ patients were also 0 given intravenous glyceryl trinitrate to unload the heart and reduce coronary vasomotility. ${ }^{13}$ ? Other medications were prescribed in accordance with the individual's clinical condition.

\section{ASSESSMENT OF REPERFUSION}

Before the start of thrombolysis 12 lead electrocardiograms were obtained on a Hewlett $\delta$ Packard cardiograph 4700 A. The amount of myocardium at risk was estimated by the method of Hogg et al. ${ }^{14}$ The ST segment area was calculated for each lead showing ST elevation and measured as the area above the isoelectric line from the $J$ point to the end of the $T$ 
wave. The sum of scores for all leads provided an index of myocardial ischaemia. Patients were asked to grade the intensity of chest pain from 0 to 100 on a visual analogue scale. Then the 12 lead electrocardiograms and the intensity of chest pain were monitored every $15 \mathrm{~min}$ for 3 hours and also whenever there was a change in symptoms, ST segment shift on the monitor, or in cardiac rhythm. Blood samples were drawn to measure serum creatine kinase MB every second hour during the first 16 hours and then every fourth hour for the next 24 hours. Then serum creatine kinase MB was measured once daily until it became normal.

To speed up the initial treatment we chose to recognise reperfusion non-invasively. Reperfusion was considered to have occurred when there was a gradual reduction in the size of the ST segment shift to $<50 \%$ of the basal value accompanied by a sudden or gradual lessening of chest pain and a rapid rise in the serum concentration of creatine kinase $\mathrm{MB}$ with a peak within 13 hours of the onset of chest pain. The interval to reperfusion (reperfusion time) was measured from the start of thrombolysis to the onset of the resolution of the ST segment elevation. All the electrocardiograms, the records of the course of chest pain, and the enzymatic time-activity curves werelanalysed by two investigators who were unaware of the patient's treatment group. This non-invasive method has been validated by angiography ${ }^{15-18}$ and is currently used in clinical trials. ${ }^{190}$ Infarct size was measured according to Sobel $e t$ $a{ }^{21}$ Several experimental and clinical studies showed that measurement of infarct size by enzyme tests is feasible and meaningful after thrombolysis. ${ }^{22-24}$

\section{STATISTICAL ANALYSIS}

All values are expressed as mean (SD). Paired and unpaired $t$ tests were used to compare the means of continuous variables. $\chi^{2}$ tests (with Yates's correction when indicated) were used to compare discontinuous variables. ST segment changes as a function of time were analysed by ANOVA. A two tailed method and a 0.05 level of statistical significance were used throughout.

\section{Results}

Thirty seven patients were randomly allocated to be treated with streptokinase plus simultaneous heparin ( $n=18$, group 1 ) or streptokin-

\begin{tabular}{|c|c|c|}
\hline & Group 1 & Group 2 \\
\hline $\begin{array}{l}\text { Number } \\
\text { Age (year) } \\
\text { Female (\%) } \\
\text { Hypertension (\%) } \\
\text { Diabetes (\%) } \\
\text { Smoker (\%) } \\
\text { Hypercholesterolaemia (\%) } \\
\text { Anterior MI (\%) } \\
\text { Inferior MI (\%) } \\
\text { Prior MI (\%) } \\
\text { Mean (SD) time to treatment (min) } \\
\text { Mean (SD) ST segment area (mm²) }\end{array}$ & $\begin{array}{l}18 \\
59(8) \\
11 \cdot 1 \\
27 \cdot 7 \\
22 \cdot 2 \\
77 \cdot 7 \\
26 \cdot 3 \\
50 \\
50 \\
16 \cdot 6 \\
115(48) \\
112(62)\end{array}$ & $\begin{array}{l}19 \\
60(8) \\
26 \cdot 3 \\
31 \cdot 6 \\
15 \cdot 8 \\
78 \cdot 9 \\
52 \cdot 6 \\
47 \cdot 4 \\
15 \cdot 8 \\
118(50) \\
120(58)\end{array}$ \\
\hline
\end{tabular}

MI, myocardial infarction.

None of the variables was significantly different in the two groups.

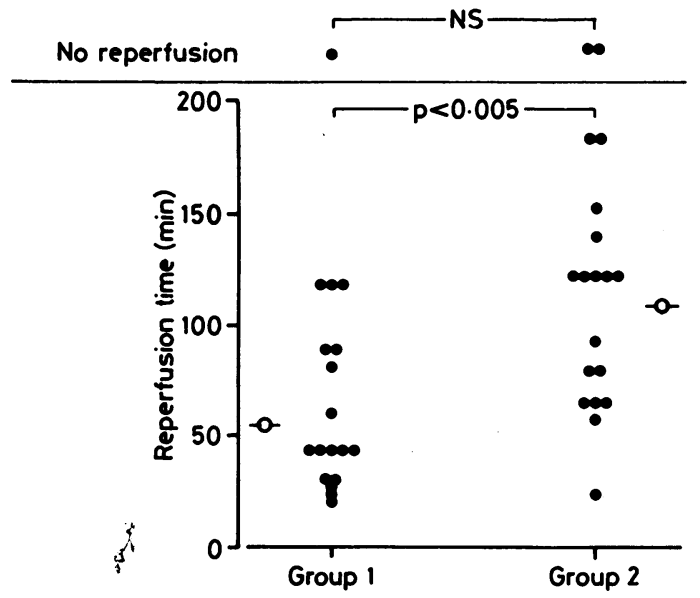

Figure 1 Reperfusion time after simultaneous (group 1) or subsequent (group 2) addition of heparin to streptokinase infusion.

ase followed by heparin ( $n=19$, group 2). Baseline characteristics were similar in the two groups (table). In particular the degree of evidence of ischaemia on the electrocardiogram at presentation was similar in both groups (the ST segment area was $112(62) \mathrm{mm}^{2}$ in group 1 and $120(58) \mathrm{mm}^{2}$ in group $2 ; \mathrm{p}=\mathrm{NS}$ ). Blinded assessment showed that 17 of the 18 patients in group 1 and 17 of the 19 patients in group 2 had non-invasive signs of reperfusion. Reperfusion time was significantly shorter in group 1 (57 (35) $\min v 101(47) \min ; \mathrm{p}<0.005)$ (fig 1). Figure 2 shows the time course of ST segment elevation. In most patients there were no statistically significant differences between the two groups up to 45 minutes after randomisation. At 60 minutes group 1 patients showed a significantly lower ST segment elevation $(p<0.05)$. The difference remained significant up to 120 minutes.

The time to peak creatine kinase MB was 8 (2) $h$ in group 1 and 10 (4) $h$ in group 2 $(p<0.05)$. On average the peak concentration of creatine kinase $\mathrm{MB}$ was $87(47) \mathrm{mU} / \mathrm{ml}$ in group 1 and $134(96) \mathrm{mU} / \mathrm{ml}$ in group 2 ( $<<0.05)$. The infarct was significantly smaller in group $1\left(25 \cdot 2(9 \cdot 8) \mathrm{g}\right.$ equivalents $\left./ \mathrm{m}^{2}\right)$ than in group $2\left(35 \cdot 1(10 \cdot 2) \mathrm{g}\right.$ equivalents $\left./ \mathrm{m}^{2}\right)$ $(\mathrm{p}<0.05)$.

Many patients developed skin haematomas. Three patients $(16.6 \%)$ in group 1 and six $(31.5 \%)$ in group 2 had major bleeding com-

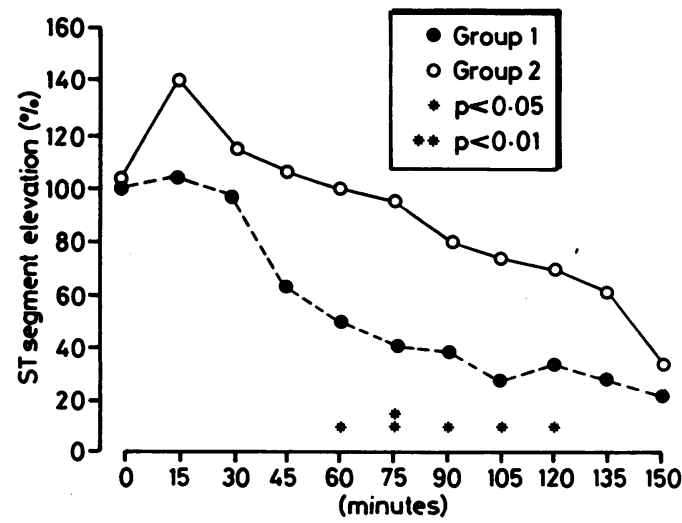

Figure 2 Time course of ST segment elevation in the two groups (percentage change $v$ baseline). 
plications. Overall, the primary bleeding site was in the genitourinary tract in seven patients and at the point of puncture for cardiac catheterisation in two patients. Five patients in group 1 and six in group 2 had early postinfarction angina. There was a reinfarction (documented by recurrence of prolonged chest pain along with typical electrocardiographic changes and a new increase in creatine kinase $\mathrm{MB}$ ) in one patient in group 1 and two in group 2.

\section{Discussion}

Acute myocardial infarction is associated with increased thrombin activity. ${ }^{910}$ The main effects of thrombin include platelet activation, fibrin formation, and impairment of fibrinolysis. $^{2526}$ Other important effects include the stabilisation of fibrin polymers and disturbance of endothelial cells that results in tissue factor induction and binding of neutrophils. ${ }^{2728}$ Evidence is now accumulating that the administration of streptokinase leads to an immediate, paradoxical increase in thrombin activity. ${ }^{112}$ This effect has several explanations. Firstly, removal of the thrombus may expose the thrombogenic surface of the infarct vessel. Reperfusion of ischaemic myocardium may be associated with a washout of thromboplastic material. Finally, thrombin absorbed on to the fibrin clot may be released by thrombolytic treatment and regain its activity. So there are strong theoretical reasons for giving heparin with streptokinase. But the possibility of bleeding complications has prevented heparin being regarded as mandatory in some recent large scale clinical trials. ${ }^{78}$

Our study shows that when heparin treatment is given there is a clear advantage in infusing it with rather than after streptokinase. This conclusion is supported by the quicker resolution of electrocardiographic signs of ischaemia and by the earlier peaking of serum concentrations of creatine kinase MB. These signs of faster reperfusion ${ }^{15} 18$ were associated with a significantly lower peak value of serum creatine kinase and a smaller infarct. Earlier studies by our group in which serum creatine kinase MB was measured frequently showed a good correlation between left ventricular function and both enzymatically assessed infarct size and the extension of resting thallium-201 perfusion defects (measured by single-photon emission tomography). ${ }^{24} 29$

The reduction of infarct size that we saw in the present study when heparin was given early was the result of a mean reduction of 44 minutes in the time to reperfusion. These data confirm that the human heart is very sensitive to the duration of ischaemia before reperfusion and support the concept that reperfusion strategies should also take account of the speed of reperfusion.

1 ISAM. A prospective trial of intravenous streptokinase in acute myocardial infarction $N$ Engl $J$ Med 1986;314:1465-71.

2 O'Rourke M, Baron D, Keogh A. Limitation of myocardia infarction by early infusion of recombinant tissue-type plasminogen activator. Circulation 1988;77:1311-5.
3 Ganz W, Geft I, Maddahi I, et al. Nonsurgical reperfusion in evolving myocardial infarction. $\mathrm{J} \mathrm{Am}$ Coll Cardio 1983;1:1247-53.

4 White HD, Norris RM, Brown MA, et al. Effect of intravenous streptokinase on left ventricular function and early survival after acute myocardial infarction. $N$ Engl $J$ Med 1987;317:850-5.

5 Kennedy JW, Martin GV, Davis KB, et al. The Western Washington intravenous streptokinase in acute myocardial infarction randomised trial. Circulation 1988;77: dial inf

6 AIMS Trial Study Group. Effect of intravenous APSAC on mortality after acute myocardial infarction: preliminary report of a placebo-controlled clinical trial. Lancet 1988;i.545-9.

7 Grupp Italiano per lo Studio della Streptochinasi nell' Infarto miocardico (GISSI). Effectiveness of intravenous thrombolytic treatment in acute myocardial infarction. Lancet 1986;i:397-401.

8 ISIS-2 (Second International Study of Infarct Survival) collaborative group. Randomized trial of intravenous streptokinase, oral aspirin, both, or neither among 17187 cases of suspected acute myocardial infarction. Lancet 1988;ii:349-60.

9 Neri Serneri GG, Gensini GF, Abbate R, et al. Increased fibrinopeptide $A$ formation and thromboxane $A_{2}$ production in patients with ischaemic heart disease: relationships to coronary pathoanatomy, risk factors, and clinical manito coronary pathoanatomy, risk factors, a

10 Small M, Lowe GDO, Dougals JT, Hutton I, Lorimer AR, Forbes $\mathrm{CD}$. Thrombin and plasmin activity in coronary artery disease. Br Heart J 1988;60:201-3.

11 Seitz R, Blanke H, Pratorius G, Strauer BE, Egbring R. Increased thrombin activity during thrombolysis. Thromb Haemost 1988;59:541-2.

12 Eisemberg PR, Sherman LA, Jaffe AS. Paradoxic elevation of fibrinopeptide A after streptokinase: evidence for continued thrombosis despite intense fibrinolysis. $J \mathrm{Am}$ Coll Cardiol 1987;10:527-9.

13 Tymchak WJ, Michorowski BL, Burton JR. Preservation of eft ventricular function and topography with combined reperfusion and intravenous nitroglycerin in acute myocardial infarction [Abstract]. $\mathrm{J} \mathrm{Am}$ Coll Cardiol 1988;11:90.

14 Hogg KJ, Lees KR, Hornung RS, Howie CA, Dunn FG, Hillis WS. Electrocardiographic evidence of myocardial salvage after thrombolysis in acute myocardial infarction. Br Heart J 1989;61:489-95.

15 Gore JM, Roberts R, Ball SP, Montero A, Goldberg RJ, Dalen JE. Peak creatine kinase as a measure of effectiveness of thrombolytic therapy in acute myocardial infarction. Am J Cardiol 1987;59:1234-8.

16 Krucoff MN, Green CE, Satler LF, et al. Noninvasive detection of coronary artery patency using continuous ST segment monitoring. Am J Cardiol 1986;57:916-22.

17 Garabedian HD, Gold HK, Yasuda T, et al. Detection of coronary artery reperfusion with creatine kinase-MB determinations during thrombolytic therapy: correlation with acute angiography. J Am Coll Cardiol 1988;11: 729-34.

18 Hogg KJ, Hornung RS, Howie CA, Hockings N, Dunn FG, Hillis WS. Electrocardiographic prediction of coronary artery patency after thrombolytic treatment in acute myocardial infarction: use of the ST segment as a nonmyocardial infarction: use of the ST segme

19 Ganz W, Geft I, Shah PK, et al. Intravenous streptokinase in evolving acute myocardial infarction. Am J Cardiol 1984;53:1209-16

20 Magnani B. Plasminogen Activator Italian Multicenter Study (PAIMS). Comparison of intravenous recombinant single-chain human tissue-type plasminogen activator $(\mathrm{rt}$ PA) with intravenous streptokinase in acute myocardial infarction. J Am Coll Cardiol 1989;13:19-26.

21 Sobel BE, Roberts R, Larson KB. Estimation of infarct size from serum MB creatine phospokinase activity: applications and limitations. Am J Cardiol 1976;37:474-85.

22 Dé Zwaan C, Willems GM, Vermeer F, et al. Enzyme tests in the evaluation of thrombolysis in acute myocardial infarction. Br Heart J 1988;59:175-83.

23 Van der Laarse A, Vermeer F, Hermens WT, et al. Effects of early intracoronary streptokinase on infarct size estimated from cumulative enzyme release rate: a randomised trial of from cumulative enzyme release rate: a randomised trial of 533 patients with acute myocardial infarction. Am Heart $J$

24 Melandri G, Tartagni F, Branzi A, et al. La stima enzimatica dell'area infartuale nei pazienti sottoposti a terapia trombolitica. Cardiologia 1988;33:61-7.

25 Gelehrter TD, Sznycer-Laszuk R. Thrombin induction of plasminogen activator-inhibitor in cultured human endothelial cell. J Clin Invest 1986;77:165-9.

26 Konkle BA, Ginsburg D. The addition of endothelial cell growth factor and heparin to human umbilical vein endothelial cell cultures decreases plasminogen activator inhibitor-1 expression. J Clin Invest 1988;82:579-85.

27 Nawroth PP, Stern DM. Endothelial cell procoagulant properties and the host response. Semin Thromb Hemost 1987;13:391-7.

28 Whatley RE, Zimmerman GA, McIntyre TM, Taylor R, Prescott SM. Production of platelet-activating factor by endothelial cells. Semin Thromb Hemost 1987;13:445-53.

29 Melandri G, Tartagni F, Branzi A, et al. Left ventricular volume response to exercise after thrombolytic therapy: relationship with tomographic and enzymatic infarct size. relationship with tomographic 